\title{
Die herlewing van 'n ou definisie van praktiese teologie
}

\author{
J I DE WET
}

\section{Inleiding}

In 1975 het Gert Otto die "Praktisch Theologisch Handbuch" by die Furche Verlag in Hamburg heruitgegee. Elke hoofstuk is deur 'n ander skrywer daargestel. Só is die boek in sy geheel die resultaat van die werk van 'n groep skrywers wat op grond van 'n gemeenskaplike uitganspunt en teologiese opvattings saamwerk. 'n Mens wil byna sê dat die boek die produk van 'n skool teoloë is.

Die uitgangspunt en opvatting op grond waarvan hierdie samewerking plaasvind, is deur Gert Otto self geformuleer. Dit verskyn as hoofstuk $l$ in die boek onder die titel "Praktische Theologie als kritische Theorie religiös vermittelter Praxis in der Gesellschaft". Hierdie titel is eintlik net 'n omskrywing van die baie ou definisie: Praktiese Teologie is die teorie van die praktyk.

Hierdie ou definisie, wat al op baie goeie gronde afgewys is, was die direkte oorsaak daarvan dat die Praktiese Teologie vir 'n baie lang tyd nie as ' $n$ wetenskap beskou is nie en ' $n$ lang stryd moes stry om erken te word as 'n volwaardige teologiese wetenskap met ' $n$ eie bestaansreg binne die teologiese curriculum. Daarom is dié vraag onvermydelik: Wat is die motief vir en doelwit met die heropname van hierdie ou, on padwaardige definisie van die Praktiese Teologie?

Otto cs gaan uit van die standpunt dat die Praktiese Teologie vandag nie meer sinvol beoefen kan word op die tradisioneel-reformatoriese wyse as wetenskaplike ondersoek en beskrywing van die kerklike dienste soos prediking, kategese en dies meer nie. Hierdie beoefening berus syns insiens op 'n dichotomistiese opvatting van kerk en wêreld waarbinne daar geen ruimte is vir die verdiskontering van hedendaags relevante vrae nie. Daarom wil hy vanuit' $n$ bepaalde religie-begrip en godsdienswetenskaplike uitgangspunt die ondersoek van wat hy "religieus bemiddelde Praxis" noem, as 'n volkome wettige teologiese taakstelling sien. Langs hierdie weg kom hy tot 'n volledige sekularisering van kerk en teologie. Vir hom is dit die enigste manier waarop die volslae wêreld- en geskiedenisloosheid waaraan die kerk, teologie en geloof ly, opgelos kan word. Terselfdertyd is dit ook die enigste manier om te verhoed dat die kerk as gevolg van realiteitsverlies doodbloei.

Dit moet sondermeer toegegee word dat die kerk in die wêreld is en dat die kerk se aktuele besig-wees in en aan die wêreld van primêre belang vir die Praktiese Teologie is. Daarom moet dit toegegee 
word dat die verhouding van kerk en wêreld altyd 'n vraag is waarmee die Praktiese Teologie worstel. Dit moet toegegee word dat die verhouding kerk-wêreld altyd kritiese korreksie nodig het, sodat die kerk nie verwêreldlik en die wêreld nie verkerklik word nie. Gert Otto se antwoord op hierdie probleem is egter nie kritiese korreksie maar herstrukturering oor die hele linie vanaf die teologiebegrip tot by die praktiese opleiding van predikante. Hierdie herstrukturering van kerk en teologie is egter nie ' $n$ teologiese vernuwing nie maar' $n$ konsekwente sekularisering van kerk en teologie. Dat dit bo alle twyfel die geval is, blyk uit 'n saaklike ontleding van die fundering wat hy vir sy definisie van Praktiese Teologie verskaf.

\section{Praktische Theologie}

Otto begin die herstrukturering van die teologiebegrip in aansluiting by die volgende stelling van Pannenberg:

"Theologie als Wissenschaft von Gott ist also nur möglich als Religionswissenschaft und Zwar nicht als Wissenschaft von den Religionen "uberhaupt, sondern von den geschictlichen Religionen. Christliche Theologie wär dann Wissenschaft von der christliche Religion, Wissenschaft vom Christentum". Pannenberg se opvatting is dat godsdienswetenskap die basiese teologiese wetenskap is. Ook Christelike teologie kan volgens hom nie anders as op die basis van 'n algemene teologie van die godsdienste bedryf word nie. Dit hang ten nouste saam met sy beskouing dat God "die allesbepalende werklikheid" is wat net op verskillende maniere in die verskillende godsdienste tot uitdrukking kom. Hierdie godsopvatting is eintlik'n hipotese, en teologie is die bedrywigheid waardeur hierdie hipotese se geldigheid en waarheid aan sy eie praktiese implikasies gemeet en getoets word.

Otto sluit by hierdie beskouing van Pannenberg aan en gaan dan 'n tree verder. Hy verwyt Pannenberg dat hy sy eie opvatting onnodig relativeer deur aan die Christendom 'n uitsonderingsposisie binne die godsdienste toe te ken. Vir hom is teologie sonder enige uitsondering teologie van die godsdienste. So verruil Otto die gedagte van 'n objektiewe selfopenbaring van God vir'n subjektiewe godsbegrip soos dit kenbaar word in die godsdienste. Hiermee laat hy vanselfsprekend ook die Skrif as bron en norm van die teologie los en vervang dit met die algemene godsdiensgeskiedenis as bron van sy teologie.

' $n$ Ander belangrike aspek in verband met sy herstrukturering van die teologie is die feit dat teologie ' $n$ komplekse aangeleentheid is. Hy kies vir "Kompläxität statt Abgrenzung".

Hiermee wil hy sy beswaar dat onderverdeling in verskillende dissiplines tot verenging in die teologie lei, oorwin. Dit loop egter on- 
vermydelik op 'n verenging uit, want só los hy alle teologie in Praktiese Teologie op. Dit sal duidelik uit die verdere ontleding van sy gedagtes blyk.

\section{"Kritische Theorie"}

Met teorie bedoel Otto veel meer as hipotese. Teorie is 'n omvattende ondersoek van en diskussie oor enige saak in sy volledigste maatskaplike en historiese konteks en samehang met ander sake. So 'n teorie gaan nie vooraf aan die praxis waarop dit betrekking het nie, want teorie en praxis staan interafhanklik en refleksief tot mekaar in verhouding. Dit beteken dat teorie en praxis mekaar oor en weer te voorskyn roep, aanvul en korrigeer.

Hierby moet in gedagte gehou word dat hy onder praxis nie handeling of soos hy dit noem "funksionerende praktyk" verstaan nie. Praxis is veel eerder maatskaplike lewensvergestalting. In hierdie verband wil hy ook glad nie praat van beginsel en toepassing van beginsel nie, want dit is terme en begrippe van die steriele werkinglose teologie wat al klaar aan wêreld- en geskiedenisloosheid, dit is realiteitsverlies doodgebloei het.

Teorie sluit vir hom altyd onherroeplik kritiek en ontwerp in.

Kritiek is self- en saakkritiek, nie as afbrekende kritiek nie, maar wel as positief waardebepalende beoordeling of evaluasie; ontwerp is ook nie 'n grondplan wat opgestel en uitgevoer word nie. Dit is eintlik die wyse waarop die maatskappy homself van binne uit tot uitdrukking bring;

kritiese teorie beteken dus eintlik dat die samelewing met homself waardebepalend besig is en so aan homself van binne uit gestalte gee;

hierdie besigwees van dié samelewing met homself is eintlik beoefening van teologie, want dit is die wyse waarop die godsbegrip aan sy eie praktiese implikasies gemeet en getoets word;

hiermee voltrek Otto dan nog ' $n$ baie betekenisvolle verskuiwing waarvolgens teologie nie meer ' $n$ worsteling met die Woord en met die wêreld in verhouding tot en in die lig van die Woord is nie.

\section{"Religiös Vermittelter Praxis"}

Otto verwerp Barth se standpunt dat openbaring en Christelike geloof iets gans anders is as godsdiens, omdat dit 'n kloof tussen God en die geloof in Hom aan die een kant en die wêreld, ook die wêreld van die godsdienste, aan die ander kant "postuleer". Volgens hom is hierdie visie van Barth die direkte oorsaak van wat hy die geskiede- 
nis- en wêreldloosheid van die teologie, kerk en geloof noem. Vir hom is die godsvoorstellings van die verskillende godsdienste blykbaar maar net variante voorstellings van God. Daarom is ' $n$ teenstelling tussen God en die godsdienste eintlik 'n dwaasheid en 'n dwaling. Dit gaan in alle godsdienste, die Christendom ingesluit, om dieselfde God. Elke godsdiens het dus 'n bydrae te maak tot 'n religieus bediende praxis.

'n Tweede gedagte wat hy invoer om duidelik te maak wat hy met "religiös vermittelter Praxis" bedoel, is die beginsel van die veranderlikheid van die godsdiens. Veranderlikheid is die eintlike wesenskwaliteit van die religieuse praxis.

Terselfdertyd stel hy dat religie van die vroegste tye af ' $n$ samelewingsvormende krag was. Só word die voortdurende verandering van die samelewing en samelewingspatrone 'n religieuse gebeurtenis, want samelewing en religie staan nie in willekeurige wisselwerking nie, hulle bring mekaar onwillekeurig te voorskyn.

Die derde gedagte waarmee hy in hierdie verband werk, is die feit dat daar oorgelewerde konfessies en konfessionele materiaal is. Dit noem hy oorgelewerde godsdienstige stellings wat hy nader kwalifiseer as hipotese. Hierdie hipotese moet dan getoets word aan die hand van hedendaagse ervaring met die oog op die vraag in hoeverre hulle hedendaagse lewenservaring in hulle kan opneem. So bly hy getrou aan sy opvatting dat samelewing en religie mekaar as't ware genereer. En so word die religie nie net 'n al-groter-wordende saak nie; daarbinne word ook ruimte geskep vir sulke dinge soos die vryheidsbewegings, wat in baie gevalle niks anders is as terroristeorganisasies nie, as "religiös vermittelter Praxis in der Gesellschaft".

Langs hierdie weg word die dinge wat voorheen as sinkretistiese bedrywigheid bestempel en veroordeel is, tot ' $n$ wettige taakstelling en voorwaarde van Praktiese Teologie. Volgens hom het die Praktiese Teologie dan ook so ' $n$ samelewingsdimensie waarsonder dit nooit reg kan laat geskied aan die komplekse samehang tussen kerk, teologie, religie en samelewing nie. Een van die argumente wat deesdae nogal dikwels ten gunste van die opstel van nuwe belydenisskrifte geopper word, vertoon nogal 'n noue samehang met die gedagtes van Otto. Daarvolgens is die konfessies nie lewensvatbaar genoeg nie omdat daarin nie voorsiening gemaak is vir nuwe situasies nie.

\section{"In der gesellschaft"}

Otto definieer of omskryf nie die begrip "Gesellschaft" nie. Daarom is ons afhanklik van afleidings. Met "Gesellschaft" bedoel hy klaarblyklik die ongedifferensieerde en ongekwalifiseerde samelewing van mense. "Gesellschaft" beskou hy, soos dit wil voorkom, as die 
laaste werklikheid (ultimate reality) en in dié sin ook as die enigste werklikheid.

Dit is besonder opvallend dat Otto self nooit die woord "God" gebruik nie. Die woord kom in sy geskrif net voor in aanhalings uit ander mense se geskrifte. Nou wil ons nie beweer dat Otto "Gesellschaft" in die plek van God stel of daaraan 'n goddelike gestalte toeken nie. Tog kan dit ook nie ontken word dat "Gesellschaft" in sy denke 'n sterk gedeïfiseerde betekenis het nie. Dit is in elk geval 'n baie moeilike punt in sy denke wat baie duidelik konsekwent sekularisties wil wees. Die "Gesellschaft" is in elk geval so, dat religie en "Gesellschaft" mekaar oor en weer voortbring en vorm gee; en slegs omdat religie en "Gesellschaft" in hierdie verhouding tot mekaar staan, het die religie werklike realiteit, is dit nie geskiedenis- en wêreldloos nie.

In hierdie konteks moet daar ook iets gesê word oor die begrip "kerk" soos wat Otto dit gebruik.

Vir hom is die kerk "Ort institutioneller Praxis". Daarom verklaar hy eintlik kategories dat die kerke 'n bloot empiriese werklikheid is. Die kerk is dus nie 'n geloofsgrootheid nie, maar slegs 'n blote ondergeskikte manifestasie van die prinsipieel bowegeskikte Gesellschaft;

só is die kerk in elk geval nie die gewete van die gemeenskap nie, maar kampvegter vir allerlei sosio-politiese kruistogte. Kerk wat homself nog beskou as verkondiger van 'n Woord wat van bo en van buite af kom, is dan 'n kerk wat nie part en deel is van die prosesmatige wyse waarop gemeenskap en religie mekaar oor en weer genereer nie. Dit is dan ' $n$ wêreld- en geskiedenislose kerk wat geen bestaansreg het nie.

Wat is die praktiese teologie nou eintlik?

Wat Praktiese Teologie as kritiese teorie van religieus bediende praxis in die samelewing nou eintlik is, word miskien die duidelikste as 'n mens kyk na die resultate wat so 'n Praktiese Teologie oplewer. Ons noem twee voorbeelde, te wete die erediens en die opleiding van predikante.

Voordat hierdie twee sake nader toegelig word, is dit nodig om net 'n opmerking te maak oor die metode wat die Praktiese Teologie behoort te volg. Die metode noem hy die sosiaal-wetenskaplike metode. Die vernaamste fasette hiervan is nl die sosiaal-psigologiese en kommunikasie-teoretiese.

Volgens hom kan die Praktiese Teologie geen ander metode aanwend as dit die empiriese werklikheid tot sy reg wil laat kom nie. Hy sê egter nie presies wat hierdie metode alles behels nie. Uit sy stand- 
puntstelling kan egter wel afgelei word dat dit ' $n$ toetsing met die oog op die maatskaplike, psigologiese en kommunikatiewe aanvaarbaarheid al dan nie inhou, en uit sy resultate blyk dan dat dit 'n verwerking met die oog op so 'n aanvaarbaarheid ook insluit.

Wanneer die erediens nou op hierdie wyse behandel word, lei dit tot die volgende resultaat:

Kategories word verklaar dat die Christelike erediens in sy huidige gedaante ' $n$ volledige anachronisme is, gevolglik sosiaal, psigologies en kommunikatief totaal onverteerbaar;

vervolgens word ewe kategories verklaar dat erediens, godsdienshistories gesien, kultus is. Kultus op sy beurt is die wyse waarop mense probeer om die bomenslike magte te beheers;

die volgende stap is dat die sogenaamde politieke gebede, rollespeldienste, kommentaardienste en feesdienste gewettig word as herstrukturerings van die gemeentelike erediens. In hierdie dienste wat selfs met eet, drink en dans gevier kan word soos Kirchentag van 1973, kom volgens Otto c s tot uitdrukking dat erediens betekenisvolle ritueel is waarin die deelnemers volkome vry is en ook in staat gestel word om die magte wat hulle lewe bedreig, te oorwin.

Ook is die erediens hiermee volledig gesekulariseer en ook volledig ontkersten.

Die tweede voorbeeld van die resultaat van Praktiese Teologie as kritiese teorie van religieus bemiddelde praxis in die samelewing, is die hergestruktureerde opleiding van predikante.

Van oudsher het die Praktiese Teologie ten nouste met die opleiding van predikante te maak gehad. Die doel van die beoefening van die vak was juis om vir die kerk goedtoegeruste predikante te vorm. Daarom is die vak beoefen om die predikant as teologies-geskoolde prediker, kategeet en pastor te vorm om die Woord doelmatig aan die gemeente te kan uitlê;

vir Otto is hierdie opleiding volkome realiteitsloos, en stel hy voor dat weggedoen moet word met die verskillende dissiplines sowel as die akademiese aard van die opleiding. Dit moet vervang word met projekstudies en probleem-georiënteerde opleiding. Hierin gaan dit dan om vaardigmaking in die begeleidingstegnieke waarvoor teologiese skoling nie prinsipieel noodsaaklik is nie;

dit is duidelik dat met hierdie opleiding die predikantskap prinsipieel anders gesien word as in die tradisionele, Reformatoriese beskouing. In hierdie nuwe is die predikant begeleier van mense deur hulle aardse nood wat nie noodwendig beteken dat hy ook in Bybelse sin hulle geestelike versorger is nie. So be- 
land die predikant op die voorpunt van kruistogte vir politieke regte, meer vrye tyd vir werkers, studente- en arbeiderinspraak en dies meer, en nie noodwendig op die kansel en wat daarmee saamhang nie.

\section{Slotopmerking}

Die kerk is in die wêreld, maar nie van die wêreld nie. 'n Kerk en teologie wat só van die wêreld word dat dit nie meer die "Gegenüber" van die Woord van God aan die wêreld kan bring nie, het homself verloën en die wêreld in die steek gelaat. So 'n kerk en teologie is dan niks anders as ' $n$ skakel in die vereensamendste monoloog wat denkbaar is nie. Die wêreld wat waardebepalend met homself in gesprek is, praat soos ' $n$ waansinnige met homself en sluit hom in homself op. Hy verwag van homself wat hy nie aan homself kan bied nie. Daarom is die herlewing van die ou definisie van die Praktiese Teologie nie ' $n$ bate nie. Dit is 'n bedreiging nie soseer van die kerk as van die wêreld nie, want dit kan die wêreld net daartoe lei dat hy sy eie uitsiglose kerker word. Juis omdat God dit nie wil nie, is die kerk in die wêreld maar nie van die wêreld nie en is Praktiese Teologie 'n teologiese wetenskap en nie 'n godsdienshistoriese herontwerp van kerk en teologie nie. 
